\title{
Pillar Algorithm in K-Means Method for Identification Health Human Resources Availability Profile in Central Java
}

\author{
M. Nishom ${ }^{1}$, Sharfina Febbi Handayani ${ }^{2}$, Dairoh $^{3}$ \\ ${ }^{1,2,3}$ Politeknik Harapan Bersama, Tegal, Indonesia \\ ${ }^{1}$ nishom@poltektegal.ac.id, ${ }^{2}$ sharfina.handayani@poltektegal.ac.id, \\ ${ }^{3}$ dairoh@poltektegal.ac.id
}

\begin{abstract}
Based on data from the Ministry of Health, the distribution ratio between health workers and patients in Indonesia is still not equal distributed. It influenced by the distribution of health human resources that are not in accordance with the ideal needs of health services. This results need to identify the profile of the availability of health human resources in Indonesia. In this study, an approach will be implemented to identify the profile of health human resources availability using K-Means Clustering with a combination of pillar algorithms in optimizing the selection of the initial cluster centroid. Chisquare analysis is used to determine the disparity in the needs of health human resources with the conditions of the availability of health human resources in the Central Java region. The data collection method used in this research is the observation method, while the scientific method used in this research is the K-Means Clustering method. The results showed that the application has been generated can dynamically determine the health human resource cluster based on the disparity category of health human resource availability in the Central Java region. In addition, the labeling of the Pillar K-Means cluster based on the Chisquare test has a high degree of accuracy, namely $80 \%$.
\end{abstract}

Keywords: clustering, pillar algorithm, K-Means, health human resource

\section{INTRODUCTION}

The availability of adequate health human resources is one of the important factors in health development efforts in Indonesia, both in quality and quantity. However, the availability of health human resources in Indonesia is faced with two main problems, namely meeting the needs of health workers that are not in accordance with regional needs and the unequal distribution of health human resource [1]. Based on Indonesian Minister Health Regulation No. $81 /$ MENKES / SK / I / 2004 concerning Guidelines for the Preparation of Human Resources Planning for Health at the Provincial, District / City Levels and hospitals, namely health need methods, health service demand methods, health service target methods, and ratio methods [2]. One method of compiling the human resource requirements for health is determined using the ratio of personnel to a certain value, such as population, hospital beds and others. According to WHO standards, the maximum ratio of doctors to a population is 1: 1000 [3], but the results of data processing by the Indonesian Ministry of Health and the National Socio-Economic Survey (SUSENAS) of the Central Bureau of Statistics in 2019 show one doctor in an area must serve more than 1000 people [4]. Therefore it is necessary to have a grouping of health personnel profiles which aims to identify disparities in the needs of heath human resources compared to the real conditions of the availability of health human resources in Central Java Indonesia.

Clustering is a method or method commonly used to group data sets into a cluster, looking for and grouping data that have similarities or similarities between one data and another in a dataset. The nature of this method is unsupervised or without direction (meaning that this method is implemented without any training or training and no teacher) and does not require a target or output target. The purpose of clustering is to create clusters that are internally coherent, but distinct from one another. In other words, the data in a cluster must be as similar as possible and in one cluster must be as different as possible from the data in other clusters [5]. One of the most widely used data mining algorithms in research is K-Means[6], this is because the K-Means algorithm has the ability to classify large amounts of data with relatively fast and efficient computing time [7]. The KMeans algorithm is an algorithm that can be used to group data into several clusters based on the level of similarity between the data. This algorithm is popular because it is easy to implement in various types of cases and data attributes [8]. The use of cluster analysis can be used to classify data on the availability of health human resources in an area into a number of clusters according to the level of data similarity. This algorithmic process 
of idea or flow is quite simple. In the initial stage, first the number of groups or clusters that will be used is determined. Then proceed by selecting the first document or first element in a cluster to be used as the cluster center point. Then iteration or repetition of the steps in determining the distance of the document or object to the centroid, until stability occurs and all object groups have converged [9].

The pillar algorithm is able to optimize the selection of the initial centroid and increase the accuracy of the segmentation process in the K-means algorithm. The pillar algorithm is also able to handle outliers with an outlier detection mechanism. In addition, the execution time of the pillar algorithm also shows better performance than other early centroid optimization algorithms [7-8]. Previous research has proposed a new approach to solve the determination of the optimal starting point for K-Means, namely by optimizing the initial centroid for K-Means by spreading the initial center point in the feature space so that the distance between the centroids can be as far as possible. The results show that the proposed method can improve the initial centroid performance for K-Means by $60.2 \%$, increasing the closeness of the initial centroid, which means that the proposed approach can produce a closer initial centroid than random initialization [10].

\section{METHOD}

This study uses combination of the pillar algorithm and K-Means algorithm which aims to obtain information related to the results of the centroid determination in the pillar algorithm by grouping data against each cluster center point obtained from the results of the pillar algorithm using the K-Means algorithm (Fig. 1). The Chi-square test method was used to test the level of accuracy and to determine the homogeneity of the cluster. This study used secondary data obtained from Human Resources Development and Empowerment Directorate of the Ministry of Health of the Republic of Indonesia.

First, before entering the clustering process, an analysis of the existing data types is needed, whether the data needs to be normalized or not. The normalization that can be used is the Min-Max normalization [11]. This method is implemented by changing the original value or data to a linear form using the (1):

$$
x^{\prime}=\frac{x \text {-nilai min }}{\text { nilai } \max -\text { nilai } \min }
$$

where, $x=$ data per column, the value nilai $\min =$ the smallest value of data per column, the value nilai max $=$ the largest value of data per column.

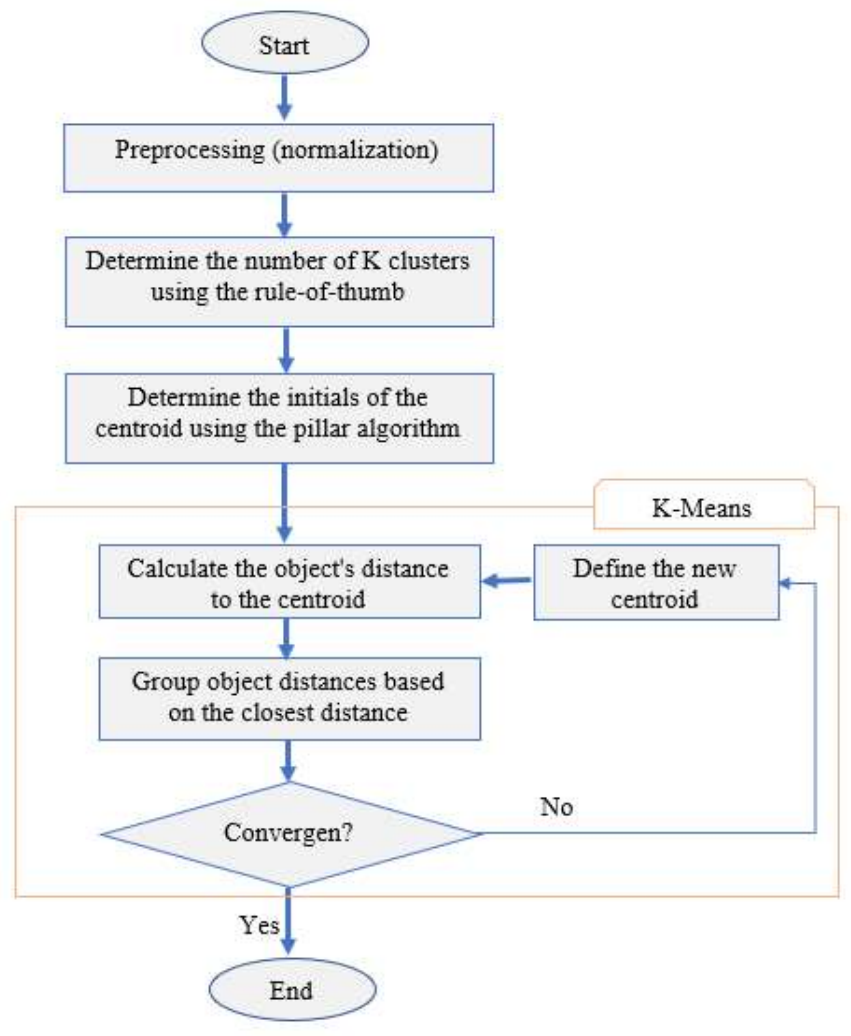

Fig. 1 Flowchart of pillar algorithm and K-Means clustering

Second, determine the number of clusters $(\mathrm{K})$. This process initializes the initial value $\mathrm{K}$ as the number of clusters to be dynamically partitioned [12]. Determination of the amount of $\mathrm{K}$ is done using the ruleof-thumb approach using (2):

$$
k=\sqrt{\frac{n}{2}}
$$

where, $\mathrm{n}=$ the number of objects to be grouped and $\mathrm{k}=$ the number of clusters.

Third, determine the initial centroid. The simplicity of the K-Means method is widely used because it is easy to implement and has a high level of accuracy so that it is more scalable and efficient, however the K-Means algorithm performs the initial calculation of the centroid randomly so that the accuracy of the results is less than optimal. The results of K-Means calculations are often obtained by experimenting several times and producing different clusters. The determination of the cluster center point randomly causes the K-Means method to not be able to get the best clustering results. In this study, to determine the new centroid is done by calculating the average value of the total object value in the new cluster [13] using (3): 


$$
C_{i}=\frac{\sum_{i=1}^{n} x_{i} \in s_{i}}{n}
$$

where $\mathrm{Ci}=$ new centroid to $\mathrm{i}, \mathrm{si}=$ object to $\mathrm{i}, \mathrm{xi}=$ value on object $\mathrm{i}, \mathrm{n}=$ number of data in each group.

Fourth, calculating the distance between the object and the centroid, to calculate the distance between the object and the centroid can be done using several approaches. This study uses the Euclidean Distance formula. This calculation calculates the quantitative value of the proximity measure, which can produce the distance from the object to the centroid [14]. The following is the Euclidean Distance formula which is used to calculate the distance between objects and the center of the cluster (4).

$$
\left.d(x, y)=|x-y|=\sqrt{\sum_{i=1}^{n}\left(x_{i}-y_{i}\right.}\right)^{2}
$$

where, $\mathrm{d}=$ distance between $\mathrm{x}$ and $\mathrm{y}, \mathrm{x}=$ cluster center data, $\mathrm{y}=$ data on attributes; $\mathrm{i}=$ each data, $\mathrm{n}=$ amount of data, $x i=$ data at the center of the cluster $\mathrm{i}, \mathrm{yi}=$ data on each data ith.

Fifth, grouping objects based on the closest distance (the smallest distance from all object distances to the centroid). Before grouping objects, a calculation must first be done to determine the minimum value distance. After obtaining the minimum value, the objects are grouped. The final stage is to test the convergence between the new data group and the data group in the previous process, if the new data group is the same as the previous data group (convergent), the clustering process is complete. If not, then do iteration starting from determining the center of the new cluster.

The cluster homogeneity test can be determined based on the silhouette coefficient value which can be obtained through the following steps. First, calculate the average distance from an object, for example $\mathrm{i}$ with all other objects in the cluster using (5) [15]:

$$
a_{i}=\frac{1}{|A|-1} \sum_{j \in A, i \neq j} d(i, j)
$$

where $|A|=$ amount of data in cluster $A$, and $i, j=$ index of document, while $\mathrm{d}(\mathrm{i}, \mathrm{j})=$ distance between document $i$ and document $j$.

Second, calculate the average distance from document $i$ with all documents in other clusters, and take the smallest value [16] using (6).

$$
d(i, C)=\frac{1}{|A|} \sum_{j \in C} d(i, j)
$$

Where, $d(i, C)$ is the average distance of object $i$ with all objects in other cluster $C$ where $A \neq C$ [17] in (7).

$$
b(i)=\min _{C \neq A} d(i, C)
$$

Third, calculate the silhouette coefficient with (8) [18]:

$$
s(i)=\frac{b(i)-a(i)}{\max (a(i), b(i))}
$$

where a(i) is the average distance between object $i$ and all objects $i$ and all objects in the same cluster (intracluster), $b(i)$ is the average distance between object I and all objects in the same clusteron the closest cluster.

This research was conducted in several stages, namely the stages of problem identification, data collection, system analysis and design, system development with the implementation of the pillar algorithm and the KMeans method, system testing. These stages are shown in Fig. 2. The problem identification stage begins by extracting data related to the availability of health human resources in Central Java. The second stage is data collection, which begins with observing and analyzing the condition of the availability of health human resources with the population in Central Java. The analysis and system design phase is carried out by analyzing the collected data, then proceed with designing a system design using UML. After the system design stage is complete, the next step is to build the system by implementing the pillar algorithm in determining the initial centroid and grouping the clusters into the same group. The system development is done using NetBeans IDE version 12.1 and MySQL. After the system development stage is complete, the next stage is the system testing stage using black box testing by testing system functionality and testing the performance and error level of the algorithm.

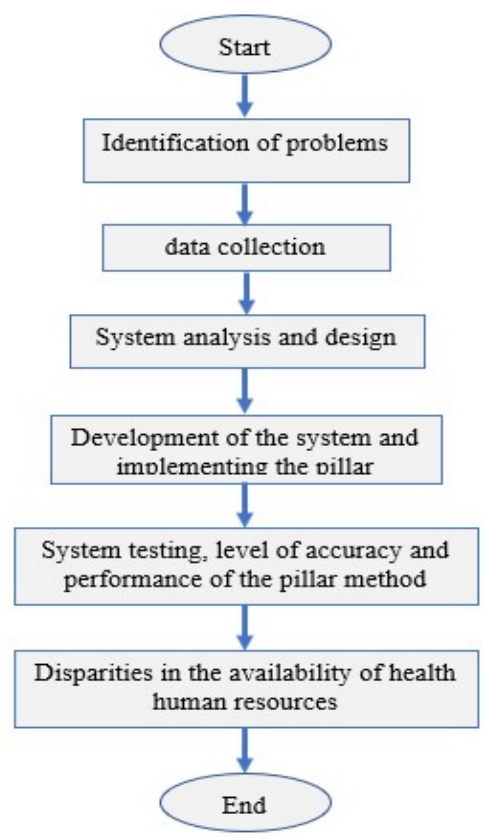

Fig. 2 Research step 


\section{RESULTS AND DISCUSSION}

The results of this study are a desktop-based application that implements the pillar algorithm and the Chi-square-based K-Means Clustering method. This application can inform the disparity of health human resource needs in each district or city in Central Java and can cluster based on the resulting disparity, and can display the accuracy of labeling on the resulting cluster so that the application of the results of this study can be used as decision support in identifying the availability profile of health human resources in the Central Java region is shown in Fig. 3.

The initial stage in this study is to find the optimal center point of the cluster or centroid using the pillar algorithm. This algorithm is inspired by the placement of pillars in a building, where the pillars must be placed at each corner of the building that is furthest away so that the mass of the building is centered on each pillar [6].
This algorithm is able to find the centroid separately as far as possible between the initial centroids in one data distribution, and can avoid selecting the outlier data as the initial centroid [7]. The implementation of the pillar algorithm in the K-Means method begins by calculating the average value of the total objects. After the average value is obtained, then the object with the highest average value is taken, a number of clusters, as shown in Table I. In this study, a rule-of-year approach was used to determine the number of clusters and produced four clusters.

After the initial centroid candidate is obtained, it is followed by calculating the average distance value of the total object value in the initial centroid candidate using the Euclidean distance. Furthermore, the dmax value (the largest value of the distance matric) is calculated to determine the new initial centroid candidate. The centroid data generated from the selection process using the pillar algorithm as shown in Table II.

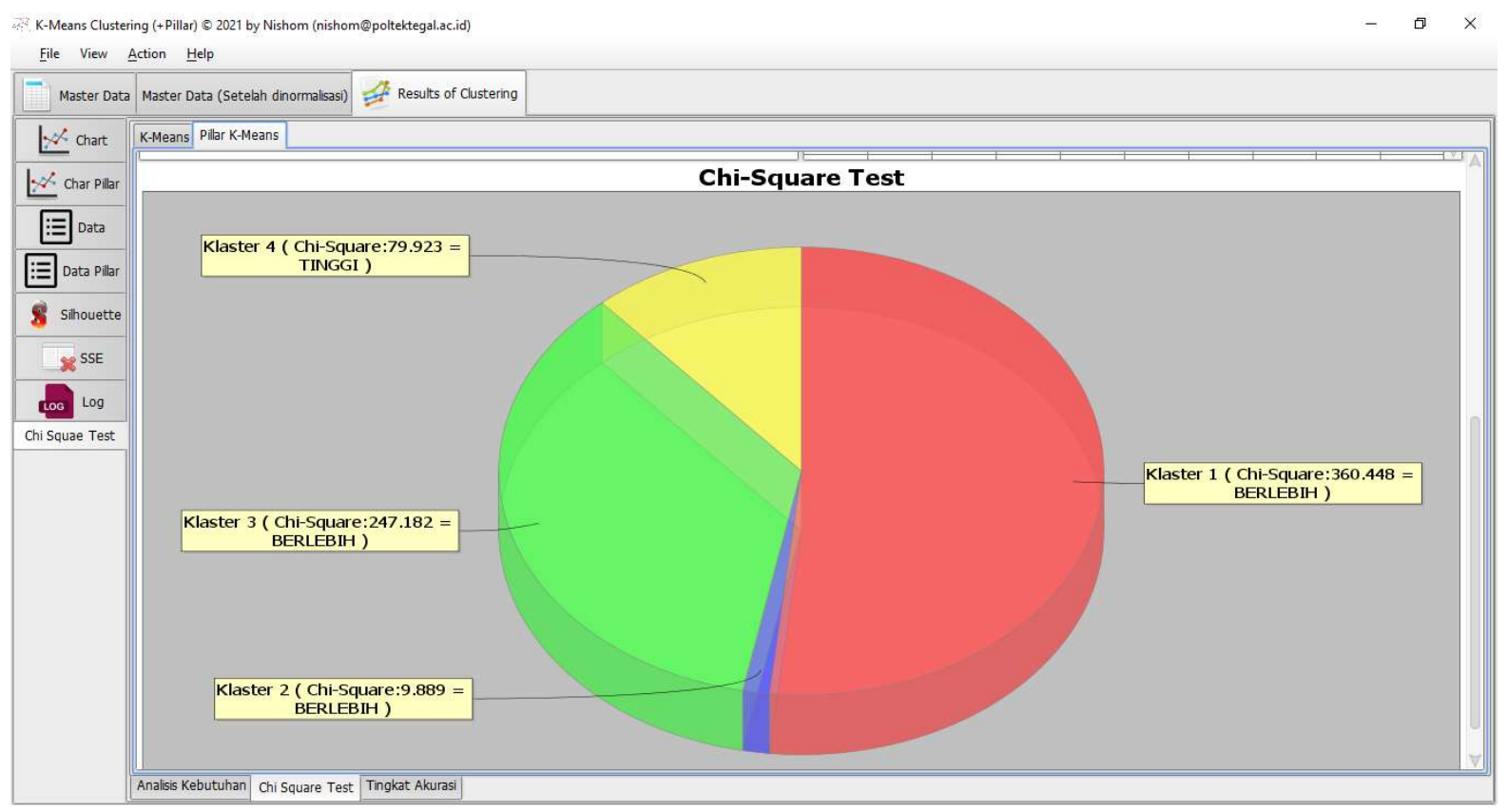

Fig. 3 Pillar - K Means application

TABLE I

CANDIDATE OF INITIAL CENTROID

\begin{tabular}{llccccc}
\hline ID & Population & Hospital & $\begin{array}{c}\text { Public Health } \\
\text { Center }\end{array}$ & $\begin{array}{c}\text { Maternity } \\
\text { Hospital }\end{array}$ & Clinic & $\begin{array}{c}\text { Medical } \\
\text { Staff(s) }\end{array}$ \\
\hline 33 & 1 & 1 & 0,941176 & 0,57971 & 0,57971 & 0,494872 \\
2 & 0,928425 & 0,769231 & 1 & 0,5 & 1 & 0,737179 \\
29 & 0,997037 & 0,384615 & 0,970588 & 0,166667 & 0,304348 & 1 \\
1 & 0,948574 & 0,346154 & 0,970588 & 0,333333 & 0,376812 & 0,802564 \\
\hline
\end{tabular}

*) Initial centroid candidate data has been normalized using the min-max method in the early stages, to minimize outliers. 
TABLE II

PILLAR ALGORITHM CENTROID

\begin{tabular}{lllcrrr}
\hline ID & Population & Hospital & $\begin{array}{c}\text { Public Health } \\
\text { Center }\end{array}$ & Maternity ospital & Clinic & $\begin{array}{l}\text { Medical } \\
\text { Staff(s) }\end{array}$ \\
\hline 1 & 0.948574 & 0.346154 & 0,970588 & 0.333333 & 0.376812 & 0.802564 \\
2 & 0.928425 & 0.769231 & 1 & 0.5 & 1 & 0.737179 \\
29 & 0.997037 & 0.384615 & 0,970588 & 0.166667 & 0.304348 & 1 \\
33 & 1 & 1 & 0.941176 & 1 & 0.57971 & 0.494872 \\
\hline
\end{tabular}

After the centroid is determined by the pillar algorithm, the next process is the normal calculation of the K-Means algorithm, which is calculating the distance of the object to the centroid, determining the distance of the object closest to the centroid, and checking the convergence of the cluster members until convergent results are found. The results of clustering of all data on health human resources in the Central Java resulted in 4 (four) clusters. The determination of the number of clusters is determined using a rule-of-thumb approach to avoid using or randomly determining the initial centroid, this is because randomly determining the initial centroid does not produce a definite cluster, fluctuating performance, and changing accuracy of the method. The clustering results are shown in Fig. 4 and Table III.

Based on Table III, there are 5 area that need further attention regarding the need for health human resources. This is due to the fact that these regions have a high number of disparities (the high number of normative needs for health human resources with the availability of health human resources). This study uses the pillar algorithm to determine the initial centroid to get good results, this is indicated by the number of stable iterations and the relatively fast execution time as well as the increased percentage of method accuracy (to $80 \%$ ) when compared to the K-Means method which does not use an algorithm. pillar as a determinant of initial centroid (with a percentage of $77.14 \%$ ). The cluster homogeneity test was carried out using the silhouette coefficient and the homogeneity test results showed that the average silhouette value for all data was 0.87 , which means that the clustering results had a high (very good or high) structure. The details of the silhouette values for each data or region are shown in Table IV.

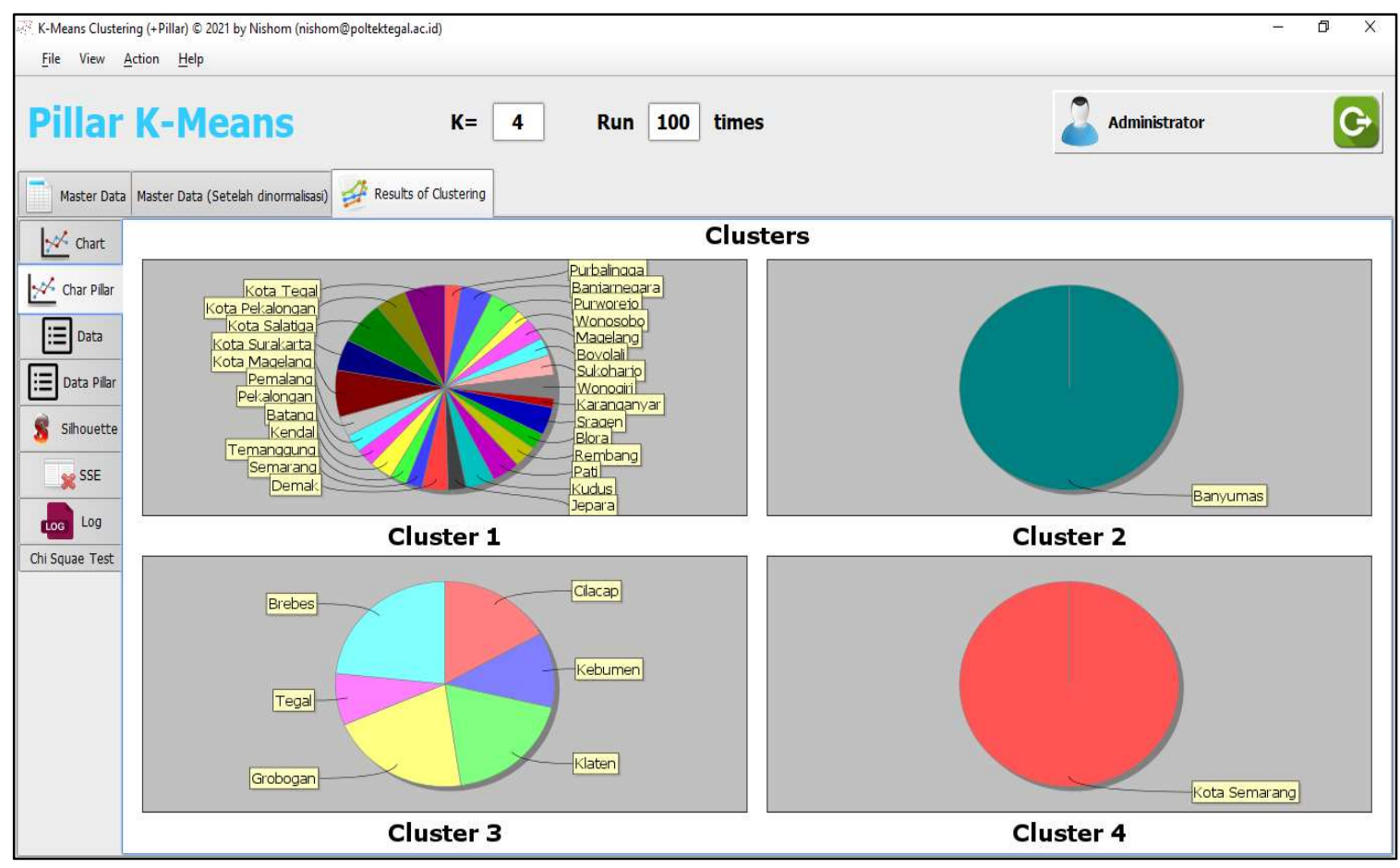

Fig. 4 Result clustering of health human resources in Central Java 
TABLE III

CLUSTERING OF HEALTH HUMAN RESOURCES PROFILE

\begin{tabular}{|c|c|c|c|c|c|c|c|}
\hline Num & Region & Cluster & Disparity & Num & Region & Cluster & Disparity \\
\hline 1 & Purbalingga & 1 & EXCESS & 19 & Kendal & 1 & EXCESS \\
\hline 2 & Banjarbegara & 1 & EXCESS & 20 & Batang & 1 & EXCESS \\
\hline 3 & Purworejo & 1 & EXCESS & 21 & Pekalongan & 1 & EXCESS \\
\hline 4 & Wonosobo & 1 & EXCESS & 22 & Pemalang & 1 & HIGH \\
\hline 5 & Magelang & 1 & HIGH & 23 & Kota Magelang & 1 & EXCESS \\
\hline 6 & Boyolali & 1 & REASONABLE & 24 & Kota Surakarta & 1 & EXCESS \\
\hline 7 & Sukoharjo & 1 & EXCESS & 25 & Kota Salatiga & 1 & EXCESS \\
\hline 8 & Wonogiri & 1 & EXCESS & 26 & $\begin{array}{l}\text { Kota } \\
\text { Pekalongan }\end{array}$ & 1 & EXCESS \\
\hline 9 & Karanganyar & 1 & EXCESS & 27 & Kota Tegal & 1 & EXCESS \\
\hline 10 & Sragen & 1 & HIGH & 28 & Banyumas & 2 & EXCESS \\
\hline 11 & Blora & 1 & EXCESS & 29 & Cilacap & 3 & EXCESS \\
\hline 12 & Rembang & 1 & EXCESS & 30 & Kebumen & 3 & EXCESS \\
\hline 13 & Pati & 1 & EXCESS & 31 & Klaten & 3 & EXCESS \\
\hline 14 & Kudus & 1 & REASONABLE & 32 & Grobogan & 3 & EXCESS \\
\hline 15 & Jepara & 1 & HIGH & 33 & Tegal & 3 & EXCESS \\
\hline 16 & Demak & 1 & EXCESS & 34 & Brebes & 3 & EXCESS \\
\hline 17 & Semarang & 1 & REASONABLE & 35 & Kota Semarang & 4 & HIGH \\
\hline 18 & Temanggung & 1 & EXCESS & & & & \\
\hline
\end{tabular}

TABLE IV

SILHOUETTE RESULT HOMOGENEITY TESTING

\begin{tabular}{|c|c|c|c|c|c|}
\hline No & Region & Silhouette & No & Region & Silhouette \\
\hline 1 & Cilacap & 0.802258056 & 19 & Kudus & 0.966568035 \\
\hline 2 & Banyumas & 0 & 20 & Jepara & 0.94659801 \\
\hline 3 & Purbalingga & 0.941197365 & 21 & Demak & 0.963013015 \\
\hline 4 & Banjarnegara & 0.969337838 & 22 & Semarang & 0.93984605 \\
\hline 5 & Kebumen & 0.718003762 & 23 & Temanggung & 0.94230083 \\
\hline 6 & Purworejo & 0.969072805 & 24 & Kendal & 0.958774377 \\
\hline 7 & Wonosobo & 0.926844024 & 25 & Batang & 0.946653909 \\
\hline 8 & Magelang & 0.958657029 & 26 & Pekalongan & 0.950330283 \\
\hline 9 & Boyolali & 0.94880627 & 27 & Pemalang & 0.954827479 \\
\hline 10 & Klaten & 0.824614488 & 28 & Tegal & 0.590519317 \\
\hline 11 & Sukoharjo & 0.955210962 & 29 & Brebes & 0.857163779 \\
\hline 12 & Wonogiri & 0.961526308 & 30 & Kota Magelang & 0.98061415 \\
\hline 13 & Karanganyar & 0.900525588 & 31 & Kota Surakarta & 0.971180558 \\
\hline 14 & Sragen & 0.967583323 & 32 & Kota Salatiga & 0.97893515 \\
\hline 15 & Grobogan & 0.840048348 & 33 & Kota Semarang & 0 \\
\hline 16 & Blora & 0.944052312 & 34 & Kota Pekalongan & 0.968938714 \\
\hline 17 & Rembang & 0.958810544 & 35 & Kota Tegal & 0.976137843 \\
\hline 18 & Pati & 0.964942903 & & & \\
\hline
\end{tabular}

The accuracy level of labeling for each region in the cluster was tested using the chi-square test. Chi-square test is used to label each cluster in general or each region regarding the level of disparity (difference between the value of availability and the value of needs) of health human resources in the Central Java region. This study uses 2 categories, namely availability and need, then the value of the degrees of freedom is $(2-1)=1$. Based on the value of degree of freedom $=1$ and error tolerance (alpha level) 0.05, the Chi-Square value is 3.841 as in (9). 


$$
\text { label }=\left\{\begin{array}{c}
\text { REASONABLE, if } X^{2}<3.841 \\
\text { High, if } X^{2} \geq 3.841 \text { and } F_{o}<F_{h} \\
\text { Excess, if } X^{2} \geq 3.841 \text { and } F_{h}<F_{o}
\end{array}\right.
$$

where $X^{2}=$ the value of chi square, $F_{o}=$ Value of the current number of health human resources, $F_{h}=$ Value The expected number of health human resources. $*$ REASONABLE $=$ The number of health human resources is adequate; $*$ High $=$ The number of health human resources needs to be increased, because it is still not sufficient $*$ Excess $=$ The number of health human resources exceeds the number of normative human resources needs. The details of the value of chi square for each data or region are shown in Table $\mathrm{V}$.

TABLE V

SILHOUETTE RESULT HOMOGE

\begin{tabular}{|c|c|c|c|c|c|c|c|}
\hline Num & Region & $\begin{array}{c}\text { Medical } \\
\text { Staff(s) } \\
\text { (Availability) }\end{array}$ & $\begin{array}{l}\text { Medical } \\
\text { Staff(s) } \\
\text { (Needs) }\end{array}$ & $\begin{array}{c}\text { Medical } \\
\text { Staff(s) } \\
\text { (Expected) }\end{array}$ & $\begin{array}{c}\text { Chi-Square } \\
\text { (Availability) }\end{array}$ & $\begin{array}{c}\text { Chi-Square } \\
\text { (Needs) }\end{array}$ & $\begin{array}{c}\text { Chi-Square } \\
\text { (Expected) }\end{array}$ \\
\hline 1 & Cilacap & 2034 & 1727 & 1880 & 12.615 & 12.452 & 25.066 \\
\hline 2 & Banyumas & 1881 & 1693 & 1787 & 4.945 & 4.945 & 9.889 \\
\hline 3 & Purbalingga & 1197 & 933 & 1065 & 16.361 & 16.361 & 32.721 \\
\hline 4 & Banjarnegara & 1616 & 923 & 1269 & 94.885 & 94.339 & 189.224 \\
\hline 5 & Kebumen & 1530 & 1197 & 1363 & 20.461 & 20.217 & 40.679 \\
\hline 6 & Purworejo & 1196 & 718 & 957 & 59.688 & 59.688 & 119.375 \\
\hline 7 & Wonosobo & 893 & 790 & 841 & 3.215 & 3.093 & 6.308 \\
\hline 8 & Magelang & 997 & 1290 & 1143 & 18.649 & 18.906 & 37.555 \\
\hline 9 & Boyolali & 1056 & 984 & 1020 & 1.271 & 1.271 & 2.541 \\
\hline 10 & Klaten & 1276 & 1174 & 1225 & 2.123 & 2.123 & 4.247 \\
\hline 11 & Sukoharjo & 1025 & 891 & 958 & 4.686 & 4.686 & 9.372 \\
\hline 12 & Wonogiri & 1100 & 959 & 1029 & 4.899 & 4.762 & 9.661 \\
\hline 13 & Karanganyar & 1007 & 886 & 946 & 3.933 & 3.805 & 7.739 \\
\hline 14 & Sragen & 713 & 890 & 801 & 9.668 & 9.889 & 19.557 \\
\hline 15 & Grobogan & 1793 & 1377 & 1585 & 27.296 & 27.296 & 54.592 \\
\hline 16 & Blora & 1495 & 865 & 1180 & 84.089 & 84.089 & 168.178 \\
\hline 17 & Rembang & 831 & 638 & 734 & 12.819 & 12.556 & 25.375 \\
\hline 18 & Pati & 1582 & 1259 & 1420 & 18.482 & 18.254 & 36.736 \\
\hline 19 & Kudus & 893 & 871 & 882 & 0.137 & 0.137 & 0.274 \\
\hline 20 & Jepara & 872 & 1257 & 1064 & 34.647 & 35.008 & 69.655 \\
\hline 21 & Demak & 1322 & 1162 & 1242 & 5.153 & 5.153 & 10.306 \\
\hline 22 & Semarang & 1070 & 1053 & 1061 & 0.076 & 0.060 & 0.137 \\
\hline 23 & Temanggung & 919 & 772 & 845 & 6.480 & 6.307 & 12.787 \\
\hline 24 & Kendal & 1488 & 971 & 1229 & 54.582 & 54.161 & 108.743 \\
\hline 25 & Batang & 1113 & 768 & 940 & 31.839 & 31.472 & 63.312 \\
\hline 26 & Pekalongan & 1415 & 897 & 1156 & 58.029 & 58.029 & 116.057 \\
\hline 27 & Pemalang & 1006 & 1302 & 1154 & 18.981 & 18.981 & 37.962 \\
\hline 28 & Tegal & 1799 & 1440 & 1619 & 20.012 & 19.791 & 39.803 \\
\hline 29 & Brebes & 2496 & 1809 & 2152 & 54.989 & 54.670 & 109.658 \\
\hline 30 & Kota Magelang & 156 & 122 & 139 & 2.079 & 2.079 & 4.158 \\
\hline 31 & Kota Surakarta & 651 & 519 & 585 & 7.446 & 7.446 & 14.892 \\
\hline 32 & Kota Salatiga & 264 & 194 & 229 & 5.349 & 5.349 & 10.699 \\
\hline 33 & Kota Semarang & 1314 & 1814 & 1564 & 39.962 & 39.962 & 79.923 \\
\hline 34 & Kota Pekalongan & 484 & 307 & 395 & 20.053 & 19.605 & 39.658 \\
\hline 35 & Kota Tegal & 318 & 249 & 283 & 4.329 & 4.085 & 8.413 \\
\hline
\end{tabular}




\section{CONCLUSION}

The implementation of the pillar algorithm and the chi-square-based K-Means method was successfully applied to the clustering application of the availability of health human resources in Central Java. The results of the chi-square test show that of the 4 (four) clusters produced, there are 5 (five) clusters that are district / city areas that have HIGH disparity rates. The evaluation results show that the level of accuracy in the disparity labeling of health human resources is $80 \%$. Based on the labeling, it can be seen that the regencies or cities with HIGH disparity status are Magelang, Sragen, Jepara, Pemalang, and Semarang City.

\section{ACKNOWLEDGMENT}

This research supported by Politeknik Harapan Bersama in 2020 through an institutional research fund scheme, contract number: 035.16/P3M.PHB/XI/2020.

\section{REFERENCES}

[1] Dinas Kesehatan Provinsi Jawa Tengah, "Buku Data Dasar Puskesmas \& Rumah Sakit Tahun 2019," Available: https://dinkesjatengprov.go.id/v2018/wpcontent/uploads/2020/09/Buku-Data-Dasar-Puskesmasdan-RS-2019.pdf, 2020. [Online]. [Accessed: 11-Nov2020.

[2] A. Kurniati and F. Efendi, Kajian Sumber Daya Manusia Kesehatan di Indonesia, Jakarta: Salemba Medika, 2012.

[3] WHO, "Global Health Workforce statistics database," https://www.who.int/gho/health_workforce/physicians_ density/en, 2020. [Online]. [Accessed: 23-Nov-2020].

[4] Anindhita Maharrani, "Distribusi tenaga kesehatan tak kunjung merata," https://lokadata.id/artikel/distribusitenaga-kesehatan-tak-kunjung-merata, 2020. [Online]. [Accessed: 18-Nov-2020].

[5] C. D. Manning, An Introduction to Information Retrieval. Cambridge: Cambridge University Press, 2009.

[6] X. Wu et al., "Top 10 algorithms in data mining," Knowl. Inf. Syst., vol. 14, no. 1, pp. 1-37, 2008.

[7] A. R. Barakbah and Y. Kiyoki, "A pillar algorithm for Kmeans optimization by distance maximization for initial centroid designation," IEEE Symposium on Computational Intelligence and Data Mining, pp. 61-68, 2009.
[8] B. B. Bhusare and S. M. Bansode, "Centroids Initialization for K-Means Clustering using Improved Pillar Algorithm,"International Journal of Advanced Research in Computer Engineering \& Technology (IJARCET), vol. 3, no. 4, pp. 1317-1322, 2014.

[9] O. J. Oyelade, O. O. Oladipupo, and I. C. Obagbuwa, "Application of $\mathrm{k}$ Means Clustering algorithm for prediction of Students Academic Performance," International Journal of Computer Science and Information Security (IJCSIS), vol. 7, pp. 292-295, 2010.

[10] A. R. Barakbah and A. Helen, "Optimized K-means : an algorithm of initial centroids optimization for K-means," Semin. Soft Comput. Intell. Syst. Inf. Technol., 2005.

[11] Gde Agung Brahmana Suryanegara, Adiwijaya, and Mahendra Dwifebri Purbolaksono, "Peningkatan Hasil Klasifikasi pada Algoritma Random Forest untuk Deteksi Pasien Penderita Diabetes Menggunakan Metode Normalisasi," J. RESTI (Rekayasa Sist. dan Teknol. Informasi), vol. 5, no. 1, pp. 114-122, 2021.

[12] T. Alfina, B. Santosa, and A. R. Barakbah, "Tahta Alfina, Budi Santosa, dan Ali Ridho Barakbah Jurusan Teknik Industri, Fakultas Teknologi Industri, Institut Teknologi Sepuluh Nopember (ITS) Jl. Arief Rahman Hakim, Surabaya 60111," J. Tek. POMITS, vol. 1, no. 1, pp. 1-5, 2012.

[13] A. Hadi, "Segmentasi Pelanggan Internet Service Provider (ISP) Berbasis Pillar K-Means," J. Ilm. Teknol. Inf. Asia, vol. 13, no. 2, pp. 151, 2019.

[14] S. K. Dini and A. Fauzan, "Clustering Provinces in Indonesia based on Community Welfare Indicators," EKSAKTA J. Sci. Data Anal., vol. 1, no. 1, pp. 56-63, 2020.

[15] A. R. Barakbah and Y. Kiyoki, “A pillar algorithm for kmeans optimization by distance maximization for initial centroid designation," 2009 IEEE Symp. Comput. Intell. Data Mining, CIDM 2009 - Proc., pp. 61-68, 2009.

[16] H. Frigui, "Clustering: Algorithms and applications," 2008 1st Int. Work. Image Process. Theory, Tools Appl. IPTA. 2008.

[17] I. H. Rifa, H. Pratiwi, and R. Respatiwulan, "Clustering of Earthquake Risk in Indonesia Using K-Medoids and K-Means Algorithms," Media Stat., vol. 13, no. 2, pp. 194-205, 2020.

[18] I. Wahyudin, T. Djatna, and W. A. Kusuma, "Cluster Analysis for SME Risk Analysis Documents Based on Pillar K-Means," Telkomnika (Telecommunication Comput. Electron. Control., vol. 14, no. 2, pp. 674-683, 2016. 